\title{
AN ENAMEL-PAINTED GLASS BOTTLE FROM A “TURKISH PIT” IN BUDA
}

\author{
Á. KollátH
}

\begin{abstract}
The fragments of a high quality, enamel painted, blue glass bottle with the date 1671 on its shoulder were found in the Castle District of Buda, in a huge pit dated to the period of the Ottoman occupation. The shape of the object shows eastern influences, while its decoration is clearly western. The origin of the bottle is probably Transylvanian, based on its characteristics and a small group of parallels.
\end{abstract}

Keywords: Buda - Castle District, Early New Age, Ottoman Empire, Transylvanian Principate, glass making workshops, eastern and western glass, enamel painting, Haban craftsmen

This article aims to describe such an object, which has the date 1671 painted on its shoulder, that seems to be out of context in a city under Ottoman rule for the first sight. In spite of this, it is not completely without analogies on the once occupied territory and its assumed origin provides new information on the connections of the three parts of Early New Age Hungary. ${ }^{1}$ Its outstanding quality and particular shape also adds to the culture and art history of the region.

\section{The site}

The excavations in the area of the former Royal Stables in the Castle District of Buda have been carried out in several stages from 1983 to 1999 by the Budapest History Museum (BTM) under the supervision of K. Magyar. ${ }^{2}$ The history of this neighbourhood can be followed through the archaeological and historiographical sources from the official founding of the settlement in the middle of the $13^{\text {th }}$ century. ${ }^{3}$

The main structural element of the vicinity had been the city wall, built in its first form quickly after king Béla the Fourth's (1235-1270) decision of relocating the inhabitants of Pest to this safer location, in fear of another Tartar invasion. This early fortification had followed closely the rim of the hill-forming rock and had been reinforced by rectangular and half-circle shaped towers. ${ }^{4}$ The foundation of the city had come together with the creation of a planned plot-system as well. The traces of simple, timber built houses with stone foundations, cellars, wells and various pits could be found through the archaeological research. As far as we know, the residents of the area were craftsmen during this period. ${ }^{5}$

The growing importance of the Castle Hill's southern part had brought a change in the life of this neighbourhood in the last third of the $14^{\text {th }}$ century. The city walls had been reerected, and some of the buildings had been demolished because of the expansion of the royal palace for the first but not for the last time. As the royal court had moved to Buda during the reign of Louis the First (1342-1382) the representative value of the locality had increased, therefore the written sources have shown a continuously rising number of nobles between the proprietors of the plots. ${ }^{6}$ By the first Turkish attack in 1526, the area has been built in mainly 
by the spacious palaces of renowned statesmen and members of the aristocracy, though the presence of a cannon foundry illustrates the increasing military activity from the end of the $15^{\text {th }}$ century. $^{7}$

The district had definitely preserved its residential character in the first part of the Ottoman occupation (1541-1598). The new immigrants had dwelled in the medieval buildings, often dividing the large interiors into smaller rooms and adding makeshift attachments, but they constructed their own, new houses as well. Numerous storage and/or refuse pits belonged to these dwellings, filled up by household waste. ${ }^{8}$

The repeated western attempts to recapture the city $(1598 ; 1602 ; 1603 ; 1684 ; 1686)$ had put this more or less peaceful life to an end. Many traces of these sieges, like burnt filling layers, cannonballs, bomb fragments and hastily dug graves with sometimes seriously injured skeletons could be observed during the excavations. The city walls had suffered severe damages more than once, thus they had always been repaired and another wall was built in 1684 behind the original one to reinforce the critically threatened section. ${ }^{9}$

\section{The find context}

The aforementioned fortification efforts required a huge amount of brick, rock and earth, and therefore it is possible, that the object, where the fragments of our glass bottle were found, can be related to them. Namely, it was a huge, amorphous pit (its size was approximately $700 \times 800 \mathrm{~cm}$ on the surface), carved $1110 \mathrm{~cm}$ deep in the rock, located between the outer, older, and the inner, to 1684 datable city walls. It fell to the southern part of section 98/1, where a house with stone pavement and a filled in basement from the occupation period were also brought to light.

The pit has been excavated between the beginning of June and the middle of August in 1998. Its profile was funnel shaped, wide on its upper part and suddenly narrowing to a diameter of $300-350 \mathrm{~cm}$. The layers removed during its formation could be found beside the pit, in a reverse stratigraphic order, the mother soil on the top and the late medieval settlement layer directly over the pit's starting level. The traces of pick-axes could be observed on the rock near the bottom of the pit. Its size and form differs from the "common Turkish pit" found by dozens in the whole inhabited area of the $16-17^{\text {th }}$ century Buda, and perhaps it was used as a quarry or can be connected otherwise to these constructions.

The pit has been filled up by degrees over a period of time with a vast quantity of refuse and debris. Its lower part, from approximately $860 \mathrm{~cm}$ to $1110 \mathrm{~cm}$ contains exclusively "Turkish" material, mixed with medieval and Bronze Age finds (it's very typical to this type of object), while the middle part from $360-390 \mathrm{~cm}$ to $800-850 \mathrm{~cm}$ shows a more mixed find composition with some characteristically late $17 \mathrm{t}^{\mathrm{h}}-$ early $18^{\text {th }}$ century glass and pottery fragments (for example white- painted, unglazed milk jugs). ${ }^{10}$ This phase can be usually connected to the first "tidying" up of the city after the reoccupation in 1686 . The upper 350 $\mathrm{cm}$ 's were filled up by building debris containing $18^{\text {th }}-19^{\text {th }}$ century pottery fragments. The archaeological experiences show, that this kind of "refilling" was often needed by larger pits, 
Preprint verzió.

because the earth began to sink over time, as the layers compressed and a more stabile fill was needed on their top.

The find material consisted of animal and human bones, brick and roof tile fragments, burnt loam, various iron and bronze fragments, a large amount of pottery and some glass. A part of the latter material could be dated to the $18^{\text {th }}$ century, but there were other $17^{\text {th }}$ century pieces besides the enamel painted bottle. In the case of this object, the glass is in such a bad state, that it required careful inspection from the restaurateur to find the matching parts. ${ }^{11}$

\section{Description of the vessel}

24 fragments of the bottle could be find that build the whole profile of the vessel. The glass is translucent and according to the microscopic survey, its original colour was blue, but the material is severely oxidized. The wall thickness is $0.2-0.5 \mathrm{~cm}$.

The form is free blown, it's $21.5 \mathrm{~cm}$ tall. The rim is fire shaped, rounded, slightly thickened, narrow its diameter is $1.4 \mathrm{~cm}$. It has a wider brim by the connection to the neck. Some kind of other material, perhaps the remains of the closure stuck around the mouth, which is now fused together with the glass and cannot be removed. The neck broadens abruptly, its diameter is $4.6 \mathrm{~cm}$, its height is $11.5 \mathrm{~cm}$. It is bulb shaped, as it narrows again by the shoulder. It is decorated on its middle part by three horizontal stripes (red-yellow-red), attended by two, white, looped lines above and under them.

The form of the vessel's body is an oblate spheroid, meaning that its full profile forms an ellipse. The yellow, thickly, curvedly painted numbers of the date 1671 are visible on the more or less flat surface of the shoulder, divided by lighter, greenish yellow, ornamental leaf motives that grow from a horizontal stripe of the same colour. There can be found three more stripes under this one, a red, a white and a bright yellow one. These stripes frame the main pattern, repeated on the lower side of the bottle and completed with a white looped line, looking alike the other two on the neck.

The central design on the body of the vessel consists of three flower garlands, separated by once white, now reddish ornamental spiral motifs between two series of vertical stripes (from left to right: red-blue-bright yellow and bright yellow-blue-red). Only one of the three dividers is intact. The garlands grow out from the vertical stripes, but the closure of their design does not reach the other border. The patterns are outlined with white, then filled with blue, greenish yellow, bright yellow and red. The three garlands are similar, but not completely identical with each other. They have been assembled from the same elements: white tendrils, simple and ruffled leaves, tulips or lilies, carnations and another simple flower motif, perhaps daisy or forget-me-not. Their depiction is fully ornamental, the composition is linear. One of the garlands is wholly symmetrical, it is placed in the middle of the picture area; the other two are a bit less strictly composed they "grow out" from the upper or from the lower corner of the picture area. 
Preprint verzió.

The lower part of the vessel is left plain. The body meets with the bottom in a curve. The bottom is concave it forms a cone, its peak pointing inwards. The traces of the pontil can be observed on its outer side.

\section{Conclusions}

It appears to be quite sure, that the object was manufactured in a Christian workshop, because its inscription uses Arabic numerals ${ }^{12}$ and the western (Gregorian or Julian) calendar. ${ }^{13}$ No exact parallel to the bottle could be found, therefore the shape and the decoration had to be examined separately.

The form seems to be the more unique feature of the object, as the contemporary western vessels show almost no similarity. The ordinary bottles of the Early New Age were following the medieval tradition, being biconical, prism formed or belonging to the group of the so called "bait bottles" (csali üveg, angastare, Angster). The latter had spheroid body with a long, narrow neck and funnel shaped mouth. ${ }^{14}$ Our vessel bears some functional resemblance to this last group, with its rather small size and round body and it is also common in them, that the fluid could be poured from their mouth nearly drop by drop, but the details do not match.

Only one artefact from the $15^{\text {th }}-16^{\text {th }}$ centuries has some shared characteristics with our object, a bottle from a well in Buda (from the site of the former Army Headquarters - Honvéd Föparancsnokság), though its proportions differ significantly. E. Mester has attributed its production to one of the smaller workshops of that time, as its quality is inferior (called Waldglas by the contemporaries). ${ }^{15}$

A form known from the $18^{\text {th }}-20^{\text {th }}$ century, the "portion bottle" (porciós üveg) is more similar to our object. It had the bulb shaped neck and was made of blue glass in some regions of Hungary (namely in Baranya county), but in this case, the mouth remained somewhat wider, as its goal was to make drinking easier. This kind of bottle was meant to hand out a daily dose of brandy (pálinka) to field workers as a part of their salary. ${ }^{16}$

Since we only have a distant parallel from a later period and there aren't any publicised, close antecedents in Hungary, where the practice of glass making was based on western (Venetian, German and later Czech) tradition, a possible eastern influence had to be taken in consideration. ${ }^{17}$ The ethnographical analogy itself pointed towards the Ottoman Empire, given that the folk art and crafts of South-Western Hungary had had tight connections with the Balkan Peninsula. ${ }^{18}$

The combination of an oblate spheroid body with an equally emphasized, narrower neck has been well known for a very long time both in the Near and Far East, regardless of the material. ${ }^{19}$ A similar shape has been also present in the glass making traditions of Egypt, Persia and Syria since the $9^{\text {th }}-10^{\text {th }}$ centuries. ${ }^{20}$ The so called glass perfume sprinklers became very popular in the $11^{\text {th }}-13^{\text {th }}$ centuries. They had some common features with our bottle, like the narrow mouth (sometimes combined with a bulb shaped neck) and often the rich 
Preprint verzió.

decoration. ${ }^{21}$ It looks like that the basic form has continued to exist through the ages, as glass bottles of this type were still used in Iran and in the Muslim areas of India in the $18^{\text {th }}-19^{\text {th }}$ centuries (though they were manufactured then in England). ${ }^{22}$ Therefore the conclusion can be drawn, that a glass maker from a territory influenced by eastern, Muslim culture or working for the Ottoman markets in Hungary and/or the neighbouring provinces (Serbia, the Rumanian Principates, etc.) could encounter with some variety of this shape, either as a glass object or as a ceramic or copper vessel and could have used it, to make his ware more appealing to the customers. According to the parallels, we can guess the function of the bottle as well: it was probably made for some kind of fluid that was rather expensive and was needed only in small amounts, for example, some kind of alcoholic beverage or perfume (so called "rose water").

Considering this, one question remains: where can be found such glass making industry that is capable of creating high quality objects and is willing to combine an eastern form with ornaments that are related only distantly to the Islamic world? Inspecting the decoration can take us closer to the answer.

The usage of blue glass, the calligraphy of the numerals and the colour combinations of the paints, just as the technique of enamel painting itself point towards a group of artefacts identified as Haban glasses. ${ }^{23}$ Only a few examples are known from this type and they differ so much in their form and decoration, that it is almost certain, that some of them were manufactured in different workshops and as the dates on the vessels show, definitely not in the same time.$^{24}$ Our bottle is the latest of them, as the other two dated artefacts have the years 1615 and 1630 painted on them. ${ }^{25}$ It is also notable, that these three items are not very similar to each other. In spite of this, the object of this article seems to be closer to two other vessels, without date. Both of them are made of translucent blue glass and are free blown. One of them is a so called pear shaped jug, dated to the middle of the $17^{\text {th }}$ century. It was purchased in 1888 by Count Jenő Lázár in Transylvania and now belongs to the collection of the Hungarian Museum of Applied Arts. ${ }^{26}$ The other one is a handled jug with spheroid body and a wider, cylindrical neck. It was found in 1997, in Budapest, on the site of 19 Szalag Street by the demolition of a baroque house, together with $17^{\text {th }}$ century finds. ${ }^{27}$ Some fragments of a fourth similar, enamel painted vessel were found in the same city, during the excavations of the Hess András Square, also in a "Turkish pit", but they are unfortunately too small for a comparative study. ${ }^{28}$

Each of the vessels has a particular shape and the style of their ornamentation is not completely identical, but they can be attributed to the same circle of workshops or perhaps masters. First of all, the horizontal separation of the decorated area by multicoloured stripes seems to be characteristic, just like the white, looped line that closes the composition. The white outlines and the small cross-hatches on the tendrils are matching with the pear shaped jug, while the depiction of the red-yellow carnation and the tendrils growing out from tulips can be linked to the vessel from the Szalag Street. The main difference between our bottle and the other two, that in this case, the composition is significantly stricter, more symmetrical and also divided vertically. The lines are less voluminously curved, giving the arrangement a 
rigid, less vivid feel. These variations can be the results of chronological distance and/or different masters, but the valid explanation will remain unclear, until more, datable specimens can be found.

The vertical separation of the three picture areas with ornamental motifs between vertical stripes is reminiscent to the triglyphs used in the antiquity to separate the often decorated metopes on the facades of buildings. This element points at a strong renaissance influence.

All of these data, the modified eastern form, the Haban and western renaissance influences on the decoration, the probable origin of a parallel indicate that the bottle was made in Transylvania. The Principate have always had tighter connections with the Ottoman Empire, as the Prince had to be accepted by the Sultan and its territory was almost completely surrounded by the occupied lands.

Furthermore quite a large community of Haban craftsmen had lived since 1622 by the grace of Prince Gábor Bethlen (1613-1629) at Alvinc. ${ }^{29}$ Although we do not have concrete information about their glass making tradition, it is probable, that this group of vessels was decorated by them. In the course of the $17^{\text {th }}$ century only two glass workshops were able to produce high quality wares in Transylvania, one in Porumbák (today Felsőporumbák/Porumbacu de Sus, RO) and one in Felsőkomána (today Comăna de Sus, RO), both founded and supported by the princely court. ${ }^{30}$ Several descriptions and inventories are known of these two structures, and it looks like, that the masters had no kilns and equipment for the second firing required for enamel painting. ${ }^{31}$

There is also some information in the contemporary written sources on the forms produced in these workshops. Apple and pear shaped bottles with caps (alma- és körtvélyforma sotus üveg) are listed among many others in one of the inventories of Anna Bornemissza, the wife of Prince Mihály Apafi the First. ${ }^{32}$ The second name can be attributed to the shape of the vessel in the Museum of Applied Arts and perhaps the first description could be true for the object of this article, though there is no evidence beyond the remains of the metal(?) lid and the actual form of the bottle. ${ }^{33}$

As it seems to be plausible, that these glass vessels were made in Transylvania, the last remaining question is that of their presence in Buda. There is a quite wide range of data on the glass trade between the Principate and the Hungarian Kingdom; consequently there is no reason to deny the possibility of a similar connection towards the Ottoman territory. ${ }^{34}$ It is also an option, that these high quality items have reached the court of the Pasha as gifts of Transylvanian embassies. The fact, that we do not know such glass vessels from other archaeological sites beside Buda, does not mean that they have reached only the capital city. Hopefully we will be able to draw a more exact picture, as more Early New Age find complexes will be studied in Hungary and in Transylvania as well. 
Acta Archaeologica Academiae Scientiarum Hungaricae 64 (2013), 173-182.

DOI: 10.1556/AArch.64.2013.1.8

Preprint verzió.

\section{References}

KATONA 1974 = I. KATONA: Habaner Gläser. Ars Decorativa 2 (1974) 61-73.

MAGYAR 2003 = K. MAGYAR: A budavári Szent György tér és környékének kiépülése. Történeti vázlat 1526-tól napjainkig (The formation of St. George Square and the changing face of it, 1526-2003.) TBM 31 (2003) 43-126.

TORONYI 2009-2010 = Sz. TORONYI: 17. századi üvegkorsó restaurálása (Restaurierung eines Glaskruges aus dem 17. Jahrhundert). BudRég 42-43 (2009-2010) 183195.

VERES 2006 = L. VERES: Üvegművességünk a XVI-XIX. században (Hungarian Glasswork Production in the $16^{\text {th }}-19^{\text {th }}$ Centuries). Miskolc 2006.

VÉGH 2003 = A. VÉGH: Középkori városnegyed a királyi palota előterében. A budavári Szent György tér és környezetének története a középkorban (Medieval city quarter in the foreground of the Royal Palace. History of the St. George Square and its surroundings in Buda). TBM 31 (2003) 7-42. 
Acta Archaeologica Academiae Scientiarum Hungaricae 64 (2013), 173-182.

DOI: 10.1556/AArch.64.2013.1.8

Preprint verzió.

\section{Illustrations}

Fig. 1. Detail of the plan of section 98/1 with the "great Turkish pit"

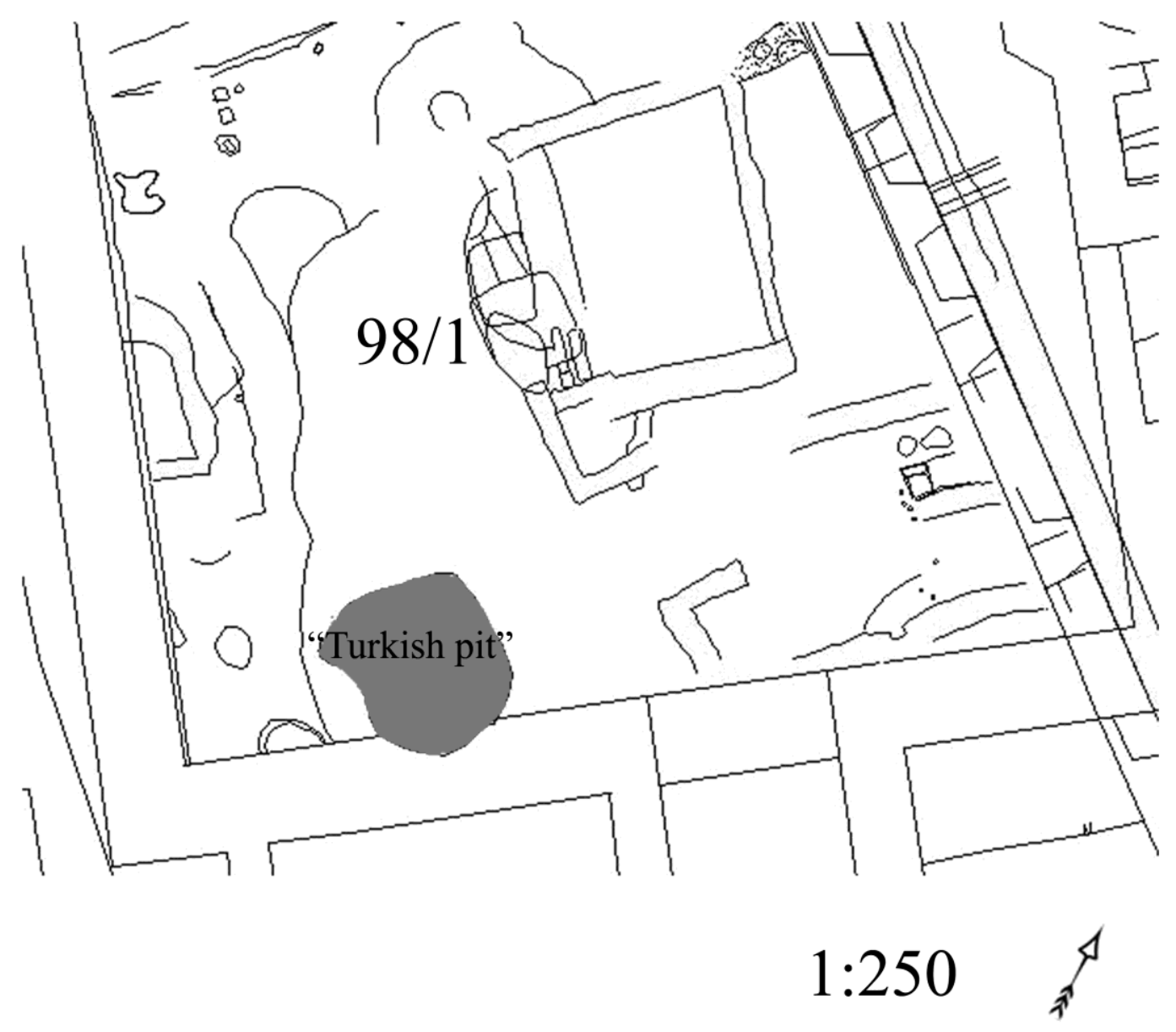


Acta Archaeologica Academiae Scientiarum Hungaricae 64 (2013), 173-182.

DOI: 10.1556/AArch.64.2013.1.8

Preprint verzió.

Fig. 2. Profile drawing of the pit

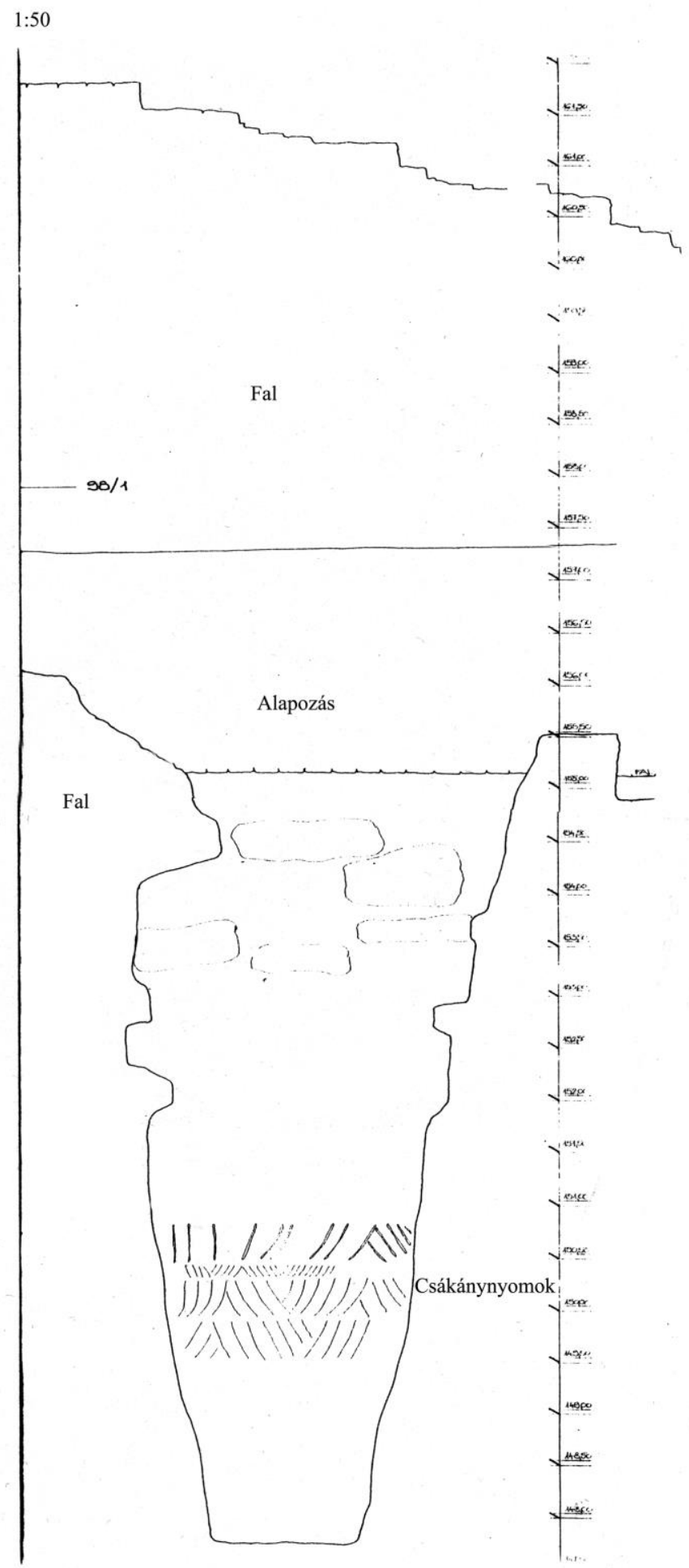


Acta Archaeologica Academiae Scientiarum Hungaricae 64 (2013), 173-182.

DOI: 10.1556/AArch.64.2013.1.8

Preprint verzió.

Fig. 3. The fragments of the bottle

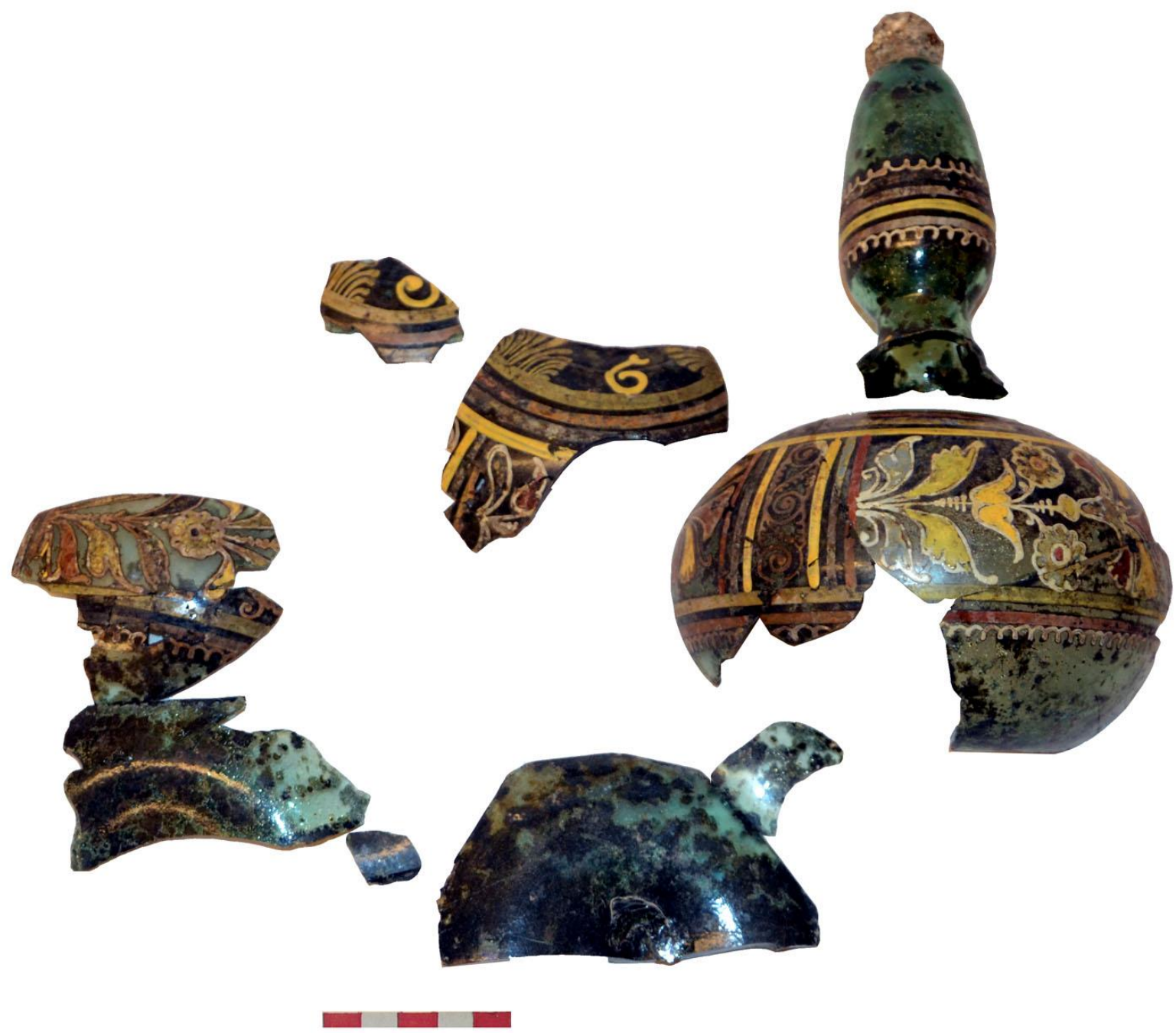

Fig. 4. Fragments with the date 1671

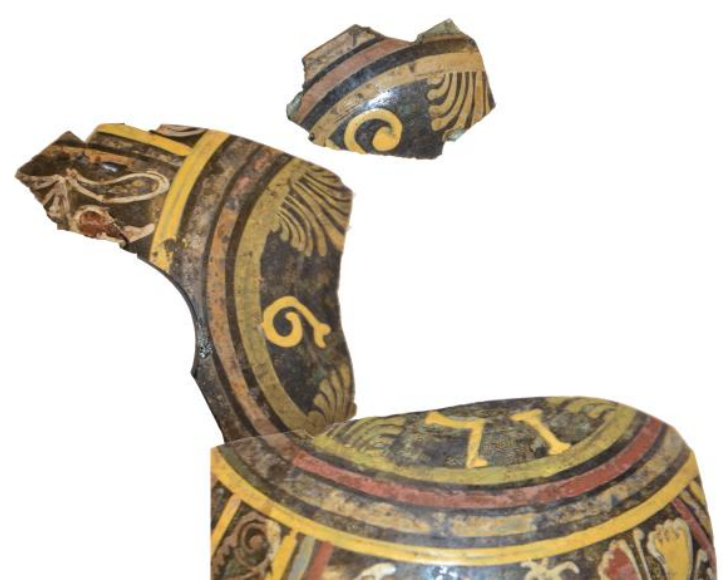


Acta Archaeologica Academiae Scientiarum Hungaricae 64 (2013), 173-182.

DOI: 10.1556/AArch.64.2013.1.8

Preprint verzió.

Fig. 5. Reconstruction of the bottle

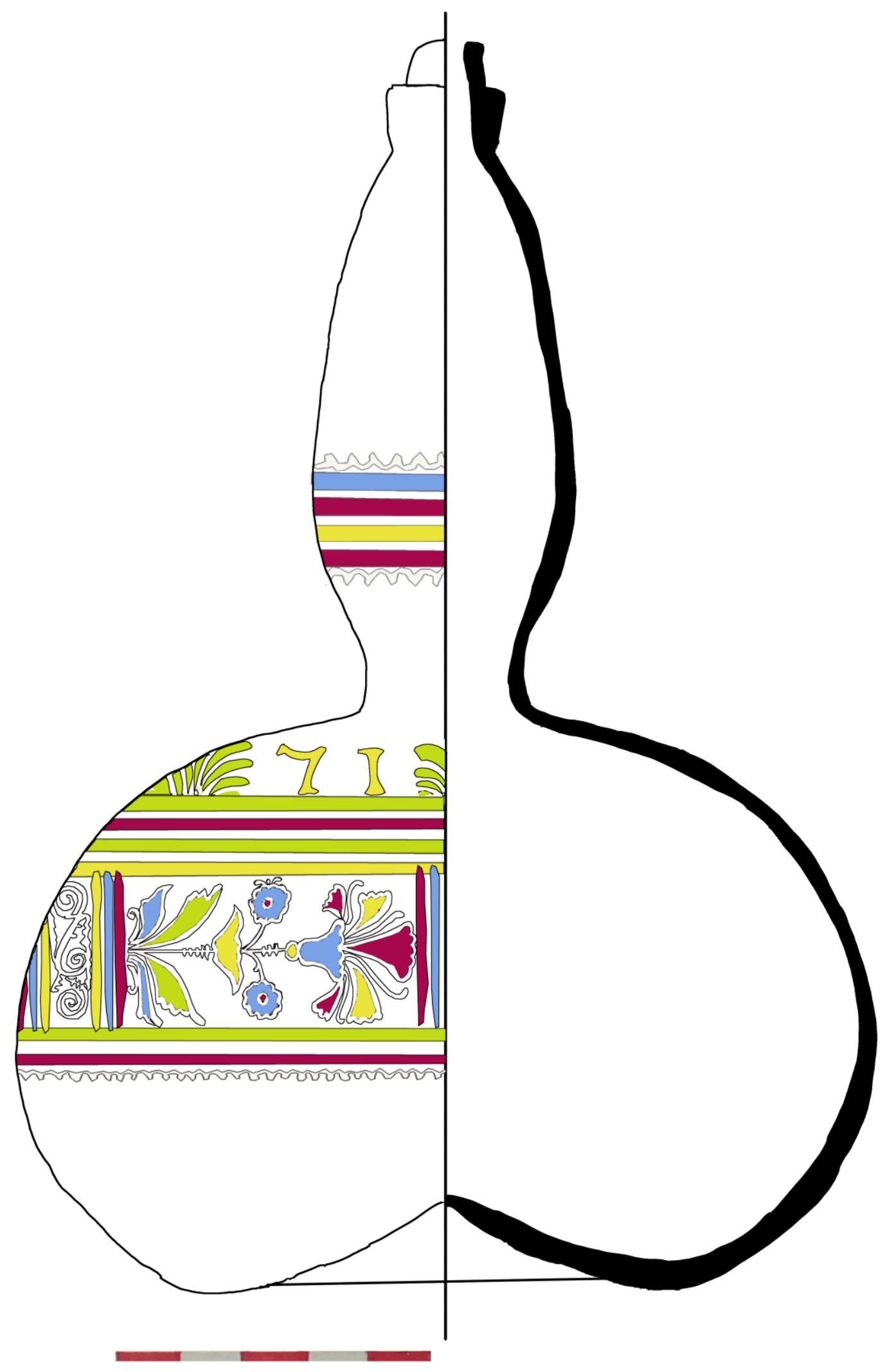


Acta Archaeologica Academiae Scientiarum Hungaricae 64 (2013), 173-182.

DOI: 10.1556/AArch.64.2013.1.8

Preprint verzió.

Fig. 6. The decoration of the bottle

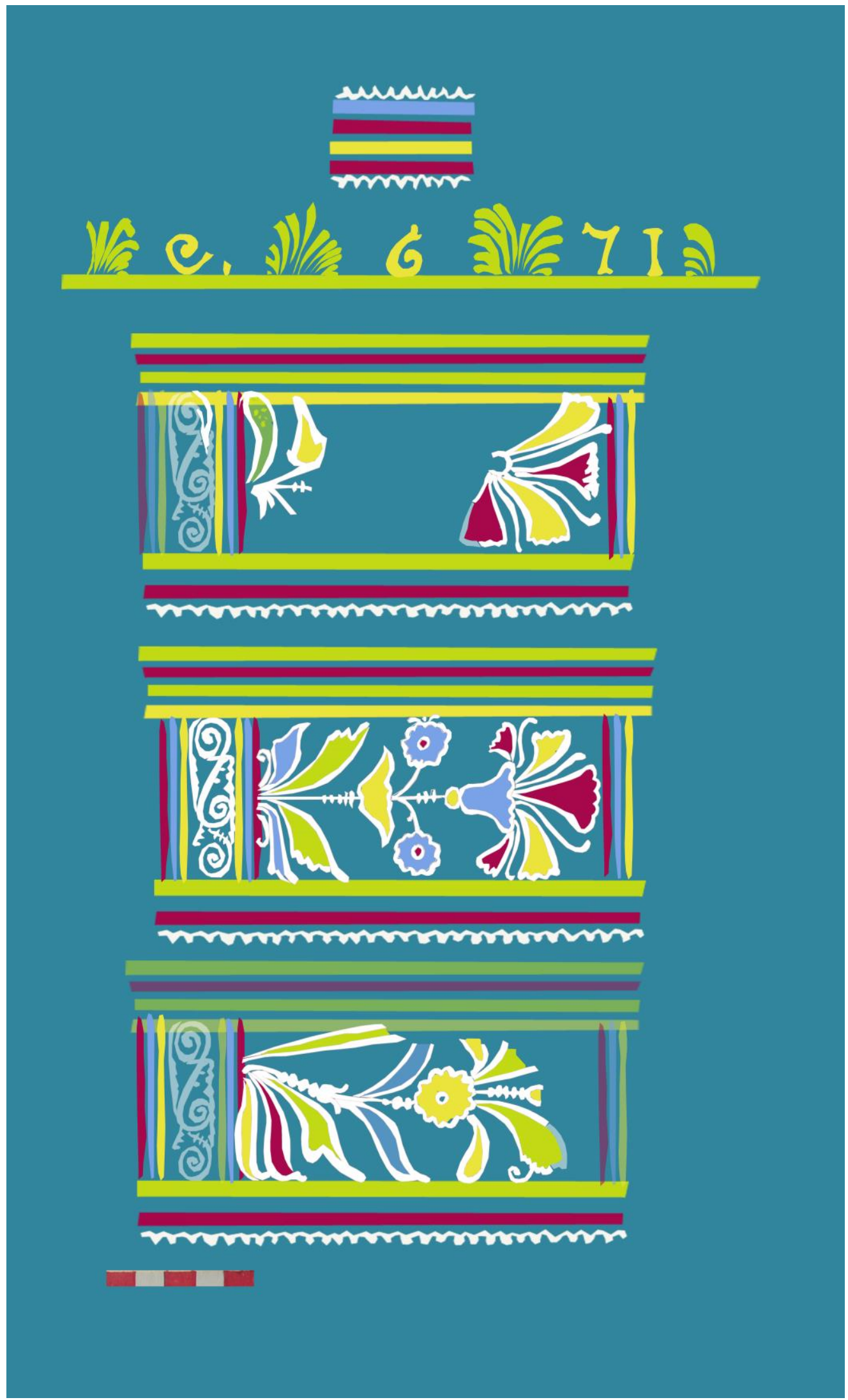


${ }^{1}$ The Hungarian Kingdom under Habsburg rule the area occupied by Ottoman armies and the Transylvanian Principate.

${ }^{2}$ I would like to thank him hereby for letting me study this material for my $\mathrm{PhD}$ thesis in progress (titled The Early New Age Pottery of Buda).

${ }^{3}$ VÉGH 2003, 10-11.

${ }^{4}$ VÉGH 2003, 10-11.

${ }^{5}$ VÉGH 2003, 12-13; 18-19.

${ }^{6}$ VÉGH 2003, 19-23.

${ }^{7}$ VÉGH 2003, 29; 32-35.

${ }^{8}$ MAGYAR 2003, 56.

${ }^{9}$ MAGYAR 2003, 56-57.

${ }^{10}$ G. HAtHÁZI-GY. KovÁCs: A post-medieval find assemblage from Vál. ActaArchHung 49 (1997) 218; 208, Fig. 10.4; 213, Fig. 13.5; 216, Fig. 15.8 .

${ }^{11}$ The restoration of the vessel is still in progress. I would like to thank K. Sárvári from the Restaurateur Department of the BTM for her caring and precise work with the object.

${ }^{12}$ It may seems to be controversial, but the countries, where the Arabic letters are in use, apply the so called "Eastern Arabic" or "Hindi" numerals, that differ in their appearance.

(http://en.wikipedia.org/wiki/Arabic numerals)

${ }^{13}$ The Gregorian calendar was introduced in 1582 by Pope Gregory XIII and it took some time to be adopted by the various protestant groups of Europe. For that reason, it is uncertain, which date calculation method was used in this case. (http://en.wikipedia.org/wiki/Gregorian_calendar)

${ }^{14}$ E. MESTER: Középkori üvegek (Medieval Glasses). Visegrád 1997, 12-14, 75-78, 82-88; VERES $2006,46$.

${ }^{15}$ E. MESTER: Üvegművesség a középkorban és a kora újkorban (Glass art in the Middle Ages and the Early Modern Age). In: E. Benkő-Gy. Kovács (eds): A középkor és a kora újkor régészete Magyarországon. II. Budapest 2010, 651, Fig. 9/12; 652.

${ }^{16}$ L. VERES: Magyar népi üvegek (Hungarian Folk Glasses) Miskolc 1989, 71-75, Fig. 36.

${ }^{17}$ VERES 2006, 39.

${ }^{18}$ Regarding the early new age and folk pottery see GY. KovÁCS: $16^{\text {th }}-18^{\text {th }}$ century pottery types. Antaeus $19-20$ (1990-91) 172-174; GY. SAROSÁCZ: A mohácsi kerámia és története (Mohačka keramika i njena historia) Pécs, 1972, 32-33; M. KRESZ: Magyar fazekasmüvészet (Hungarian Art of Pottery). Novi Sad 1991, 32-33.

${ }^{19}$ Examples of the form can be observed on copper vessels made in the Balkans up to the $20^{\text {th }}$ century. (G. FEHÉR: A pécsi Janus Pannonius Múzeum hódoltságkori török emlékei [Denkmäler aus der Zeit der Türkischen Unterwerfung im Janus Pannonius Museum in Pécs]. JPMÉ 1959 [1960] 135, Fig. 13/3.) It is also widespread among luxury ceramics like Chinese porcelain, which can be illustrated with series of bottles made under the 
rule of the Ming dynasty (1368-1663) from the Topkapı Sarayı Collection in Istanbul. (A. ÜÇOK (ed.): Chinese Treasures in Istanbul. Istanbul 2001, 34, 44.) It appears in Iznik faience as well, as a mid-16 $6^{\text {th }}$ century artefact from the Sadberk Hanim Museum proves it. (H. BILGI: Dance of Fire. Iznik Tiles and Ceramics in the Sadberk Hanim Museum and Ömer M. Koç Collections. Istanbul 2009, Cat. No. 35.) Finally, it turns up amid the so called grey jugs and glazed, "Turkish" type jugs in the area of the Ottoman occupation in Hungary. (I. HoLL: Fundkomplexe des 15-17. Jahrhunderts aus dem Burgpalast von Buda. VAH 17. Budapest 2005, 75, Fig. 39/8; S. GARÁDY: Agyagművesség (Pottery). In: L. Fekete (ed.): Budapest a török korban. Budapest Története 3. Budapest 1944, Fig. CXXXV/3.)

${ }^{20}$ D. KLEIN-W. LLOYD (eds.): The History of Glass. London 1992, 59.

${ }^{21}$ An unornamented example: S. CARBONI-D. WhiteHOUSE: Glass of the Sultans. New York 2001, 73, Cat. No. 3. A marvered vessel with two small handles: E. ATIL: Islamic Art and Patronage. Treasures from Kuwait. New York 1990, Cat. No. 62.

${ }^{22}$ S. CARBONI-D. Whitehouse op. cit. 290-291, Cat. No. 143-146.

${ }^{23}$ Allegedly made by Anabaptist craftsmen, who fled to the peripheries of Western Europe, like the Hungarian Kingdom and Transylvania at the end of the $16^{\text {th }}$ century, because they were persecuted for their religious beliefs in their homeland (Germany, France and Tirol). (L. RÉTI: The Haban Myth 1593-1738. Treasures from Hungarian private collections. Budapest 2007, 3.)

${ }^{24}$ Imre Katona has suggested, that the Anabaptists of Alvinc in Transylvania had cared for the decoration of all vessels. But there is no solid evidence for this theory as the painting styles are not identical. (KATONA 1974, 6768.)

${ }^{25}$ KATONA 1974, 65, Fig. 2; 61.

${ }^{26}$ KATONA 1974, 64. For a high quality photo, see VERES 2006, 58.

${ }^{27}$ TORONYI 2009-2010, 183. For a high quality photo see Sz. TEREINÉ TORONYI: Üvegkorsó, 17. század. (Glass jug, $17^{\text {th }}$ century.) In: P. KovÁCS (ed.): Megmentett mükincsek 2009. Diplomamunka kiállítás. Magyar Nemzeti Múzeum -Magyar Képzőmüvészeti Egyetem. Budapest 2009, Cat. No. 22.

${ }^{28}$ Unpublished. I would like to thank the leader of the excavation E. Kovács for the information.

${ }^{29}$ RÉTI op. cit. 7.

${ }^{30}$ VERES 2006, 61.

${ }^{31}$ VERES 2006, 61.

${ }^{32}$ M. BUNTA-I. KATONA: Az erdélyi üvegmüvesség a századfordulóig (Transylvanian Glassmaking till the turn of the Century.) . Bukarest 1983, 53.

${ }^{33}$ VERES 2006, 59.

${ }^{34}$ M. BUNTA-I. KATONA op. cit. 32-36. 